УДК 615.224

DOI: $10.15587 / 2519-4852.2017 .119622$

\title{
STUDY OF CONSUMPTION OF DRUGS FOR THE TREATMENT OF SOLDIERS AS SURGICAL PATIENTS IN A MILITARY MOBILE HOSPITAL
}

\section{(C) O. Bielozorova}

\begin{abstract}
Мета - провести аналіз споживання лікарських засобів для лікування військовослужбовців хірургічного профілю в умовах військового мобільного госпіталю (ВМГ).

Методи. 3 використанням кількісно-вартісного методу АВC-аналізу досліджено структуру споживання лікарських засобів (ЛЗ) хворими хірургічного профілю військового мобільного госпіталю. Матеріалами дослідження слугували звітні дані показників лікувальної роботи ВМГ за 2014-2016 рр., звіт-заявки наявності і потреби в медичному майні (ф.8/мед), статистичні та аналітичні показники захворюваності військовослужбовців (ф.3/мед), стандарти медичної допомоги , клінічні протоколи надання медичної допомоги з актуальних і найбільш значущих захворювань військовослужбовців в умовах ВМГ.

Результати. Аналіз споживання лікарських засобів для лікування військовослужбовців хірургічного профілю у військових мобільних госпіталях визначив прямо пропориійну залежність з величиною $i$ структурою госпітальної захворюваності. Лідерами споживання в грошовому вираженні стали представники групи протимікробних засобів, в кількісному - ЛЗ, щзо впливають на нервову систему.

Висновки. Отримані дані свідчать про раціональність витрачання грошових коштів на медикаментозне забезпечення досліджуваного контингенту і можуть бути використані для прогнозування потреби ЛЗ на наступний рік при плануванні медичного постачання. Також інформація про перелік ЛЗ, затребуваних у лікуванні хірургічних хворих в умовах військового мобільного госпіталю може стати основою для включення до складу клінічних протоколів надання медичної допомоги та розробки вартісних нормативів за відповідними нозологічними формами
\end{abstract}

Ключові слова: військовий мобільний госпіталь, аналіз споживання лікарських засобів, АВС-аналіз, фармакотерапевтична група

\section{Introduction}

Preservation of life and health of soldiers of the Armed Forces of Ukraine is the most important task of the medical service of the Armed Forces of Ukraine. A number of reforms in the medical care system of the Armed Forces of Ukraine are aimed at creating wellequipped, highly mobile field medical institutions that are able to effectively solve the tasks set for rendering medical assistance to wounded and sick soldiers.

One of the main factors that determine the high level of medical care is the state of logistical support. The effectiveness of medical care is directly related to the completeness and timeliness of medical supplies $[1,2]$.

The presence of a sufficiently wide range of medical property on the domestic pharmaceutical market requires the conduct of a relevant clinical and economic analysis for a justified choice of medical property, in particular medicines for use in the military medical service [3].

2. Formulation of the problem in a general way, the relevance of the theme and its connection with important scientific and practical issues

One of the most urgent scientific and practical tasks at the present time is to determine the list and volumes of medical supplies and equipment to deliver it in military mobile hospitals. Certain lists and volumes of medical stock and equipment for supplying military mobile hospitals will provide an opportunity to provide effective medical care and support the fighting ability of military personnel. All of the above was the reason for prompt viewing of the forms and methods of managing the medical supply system in order to bring the equipment of the medical service in reasonable quantitative indicators and the corresponding qualitative condition.

3. Analysis of recent studies and publications in which a solution of the problem are described and to which the author refers

After the start of military operations in the East of Ukraine, the medical supply system has raised questions of improving the supply of medical equipment to military mobile hospitals. Researches to determine the need for medical property are constantly taking place in the military medical service. In particular, were carried out studies on the problems of improving the drug supply of military personnel during polytrauma in peacetime and the rationing of medical equipment to meet the needs of medical care of military personnel in the field $[4,5]$. However, there was no attention paid to the issue of a comprehensive study of the lists and quantitative indicators of medicines in the treatment of surgical patients in military mobile hospitals. In this regard, the study of the consumption of medicines for the treatment of the studied patient population is extremely important and necessary question.

4. The field of research considering the general problem, which is described in the article

Against the background of the reform of the military medicine system, noticeable advances are also taking place in military medical supplies. In particular, there is a positive trend in the formation of the regulatory and legal framework for the organization of medical supplies in the Armed Forces of Ukraine. 
An important and topical problem at present for MMH is the absence of a separate regulated formulary list of drugs allowed for use and the regulatory requirements for drugs. A promising area of the research now is the improvement of medical treatment of soldiers and the rationale for drug use in a military mobile hospital (MMH).

\section{Formulation of goals (tasks) of article}

The aim of the study was to analyze the consumption of medicines for the treatment of military personnel under the conditions of a military mobile hospital with a view to determining the nomenclature of preparations for forming a fragment of the formulary list necessary to provide qualified medical assistance during an antiterrorist operation.

\section{Presentation of the main research material} (methods and objects) with the justification of the results In accordance with the Program for the development of the medical support system of the Armed Forces of Ukraine, in 2007, five military mobile hospitals were established at the expense of the full number of health facilities of the Ministry of Defence of Ukraine, which were the first fully deployed stages of medical evacuation (SME), which were used as multi-discipline military hospitals) for rendering qualified with elements of specialized medical care $[6,7]$. In the absence of mobile hospital bases and field centres of medical support, the MMHs acquire special significance and as a basis for the formation of groups for strengthening the medical service of military units, formations and separate military units [8]. The specificity of the work of these medical institutions is a limited period for the treatment and diagnostic process, the concentration of the contingent of patients in the life-threatening state in them.

The timeliness and correctness of the definition of the need for medicines, which occupies a significant part of the budgetary expenditures of the mobile hospital, predetermine the forecast of their consumption, and therefore the prognosis of the health status of hospitalized soldiers, the quality of their lives, influencing the direct and indirect costs of the health care system and society in general [9]. The study of the stated topic requires the analysis of the consumption of medicines in the dynamics.

To evaluate the rationality of procurement of medicines and medicinal care for patients of certain nosological groups should begin with an analysis of the structure of hospital morbidity [10]. Analysis of the structure of the incidence according to f.3/med revealed the following most common nosological forms. In 2015, the largest share in the structure of the soldiers treated in the $\mathrm{MMH}$ consisted of traumas (class XIX) - 35.5\%, the second ranking place occupied respiratory diseases (class X) $13.51 \%$, the third - diseases of the digestive system (class XI) $-9,82 \%$, on the fourth place - diseases of the musculoskeletal system and connective tissue (class XIII) $-8.51 \%$, on the fifth - diseases of the circulatory system (class IX) $-7.18 \%$. A similar situation among the five prevalent priority nosologies and in 2016, with the exception of the fourth and fifth place: the fourth place - diseases of the circulatory system $(9.95 \%)$, the fifth - diseases of the musculoskeletal system and connective tissue $(8.4 \%)$. However, against the background of the growth of the above-mentioned classes of diseases, in the class XIX "Traumas and poisonings" there is a tendency to decrease (Fig. 1).

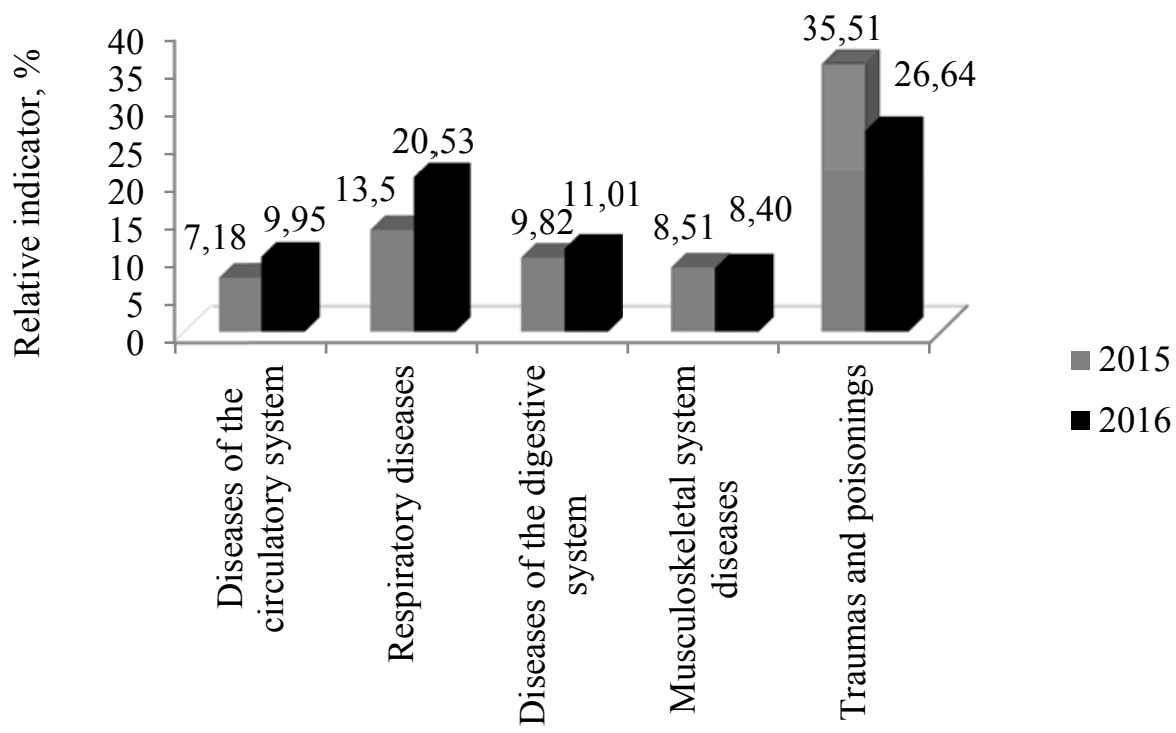

Classes of diseases by MKB-10

Fig. 1. Dynamics of changes in the five prevalent priority classes of diseases among military servicemen of the Armed Forces of Ukraine, treated in the MMH during the period 2015-2016

The results of the analysis of the structure and incidence of military personnel indicate a significant change in its structure from 2014 to 2016 . Among the main nosological forms, soldiers had respiratory sys- 
tem diseases, neurological diseases and cardiovascular diseases, which are respond to the conditions of the military service in the area of the antiterrorist operation (ATO) [11].

During the reporting period, the total number of hospitalized soldiers has decreased insignificantly (1682$2015,1647-2016)$ and the share of the category of contracted military personnel also has decreased from $97.7 \%$ to $94.6 \%$, which was caused by demobilization with a reduction in the total number of military contingents in the area of ATO.

In Table 1 was shown the distribution of the categories of hospitalized military personnel in the $\mathrm{MMH}$ for the first half of 2017 (in relative terms).

Thus, in the structure of the incoming flow of sanitary losses in the MMH, the prevalence of noncombat sanitary losses (traumatized and sick) was observed.
Table 1

Distribution of combat defeats, non-combat traumas and diseases in connection with participation in hostilities

\begin{tabular}{|c|c|c|}
\hline No. & Category & $\%$ \\
\hline 1 & Combat defeats & 18.4 \\
\hline 2 & Non-combat traumas & 17.7 \\
\hline 3 & Diseases & 63.9 \\
\hline \multicolumn{2}{|c|}{ Total } & 100.0 \\
\hline
\end{tabular}

In Table 2 was shown the quantitative indicators of the contingent of treated patients in MMH.

It should be noted that against the background of the increasing total number of treated patients from 2014 to 2016, the number of surgical profiles treated also increased. Surgical interventions were performed on urgent indications $(46 \%)$.

Quantitative indicators of the treated patients in $\mathrm{MMH}$ by profiles

Table 2

\begin{tabular}{|l|l|c|c|c|c|c|c|}
\hline \multirow{2}{*}{ No. } & \multicolumn{2}{|c|}{ Profile name } & \multicolumn{3}{|c|}{ Number of treated patients } & \multicolumn{3}{c|}{ Average duration of treatment } \\
\cline { 3 - 8 } & & 2014 & 2015 & 2016 & 2014 & 2015 & 2016 \\
\hline 1 & Surgical profile & 2972 & 2610 & 4442 & 6,8 & 7,1 & 7,1 \\
\hline 2 & Therapeutic profile & 3502 & 1678 & 1637 & 8,5 & 8,1 & 7,7 \\
\hline 3 & Total & 6474 & 4288 & 6079 & 7,7 & 7,7 & 7,5 \\
\hline
\end{tabular}

Taking into account these indicators, the subject of our research was the study of the state of drug consumption in the provision of skilled surgical care to military personnel in the conditions of military mobile hospitals. Taking into account the dynamics of the indicators of the level and structure of the incidence of military personnel, the nosologic composition of surgical profile soldiers, the implementation of new methods of treatment, the level of drug supply, individual choice by physicians of individual drugs or their groups, the main factors influencing the needs of this category of patients in drug therapy, allocating financial-economic, organizational, regulatory, pharmaceutical, technological and situational factors.

Qualitative and clinically effective drug therapy includes three elements: a range of drugs, quantitative indicators of drug costs in kind and cash costs for the acquisition of drugs.

First of all, the entire range of medicines was analyzed, which the MMH was provided during 2015-2016. Analysis of the structure of drug consumption showed growth over a certain period of the drug consumption volume, that affect the digestive system and metabolism (A) in accordance from $23.6 \%$ to $32.7 \%$, antimicrobial agents for systemic use $(\mathrm{J})$ - from $6.9 \%$ up to $17.41 \%$, drugs affecting the musculoskeletal system $(\mathrm{M})$ - from $4.6 \%$ to $7.6 \%$, medicines affecting the nervous system (N) - from $16.2 \%$ to $18.3 \%$. The volume of prescriptions of dermatological agents (D), drugs affecting the genitourinary system and sex steroids $(G)$, drugs affect- ing the sense organs (S) and various agents (V) in 2016 increased and amounted to $4.1 \%$ of the total number of drugs. In general, the structure of prescribed and consumed drugs corresponds to the structure of hospital morbidity described above. Detailed information on the changes in the drug consumption patterns of the various pharmacotherapeutic groups according to the ATC classification in the $\mathrm{MMH}$ is given in Table 3.

Obvious is the fact that in compare to 2015, a qualitative ( 57 new names instead of 27 seized) and quantitative (116 drugs were significantly increased in volume of consumption, in contrast to 34 , which decreased), modification of the assortment of medicines. This indicates that the domestic military medical service uses modern medicines in the treatment of military personnel in parallel with the development of the commodity assortment of the pharmaceutical market in Ukraine.

In Fig. 2 is shown the dynamics in the drug consumption pattern in the MMH in the period 2015-2016. Simultaneously with the trend towards an increase in the total number of medicines consumed in $\mathrm{MMH}$ from 230 to 259 trade names, the total number of consumed medicines by international nonproprietary names in the $\mathrm{MMH}$ increased from 187 to 213 INN, which is reflected in Fig. 3. The uniform nature of the increase in drug use is characteristic for all pharmacotherapeutic groups.

Analysis of the provision of medicines to surgical patients of $\mathrm{MMH}$ for the first half of 2017 showed that the available assortment consists of 189 trade names of medicines at 133 INN (Fig. 4). 
Table 3

Changes in the drug consumption structure in the MMH in 2016

\begin{tabular}{|l|c|c|c|c|}
\hline \multirow{2}{*}{$\begin{array}{c}\text { Pharmacotherapeutic groups according to the } \\
\text { ATC }\end{array}$} & \multicolumn{5}{c|}{\begin{tabular}{c} 
Number of medical products \\
\cline { 2 - 5 }
\end{tabular}} & $\begin{array}{c}\text { Included } \\
\text { items }\end{array}$ & $\begin{array}{c}\text { Seized } \\
\text { items }\end{array}$ & $\begin{array}{c}\text { Significantly reduced in } \\
\text { volume }\end{array}$ & $\begin{array}{c}\text { Increased in } \\
\text { volume }\end{array}$ \\
\hline $\begin{array}{l}\text { A - drugs affecting the digestive system and } \\
\text { metabolism }\end{array}$ & 8 & 3 & 5 & 20 \\
\hline $\begin{array}{l}\text { B - drugs affecting the blood system and } \\
\text { hematopoiesis }\end{array}$ & 3 & 3 & 6 & 14 \\
\hline C - drugs that affect the cardiovascular system & 4 & 5 & 6 & 12 \\
\hline D - dermatological medicines & 6 & 0 & 2 & 11 \\
\hline $\begin{array}{l}\text { G - drugs affecting the genitourinary system } \\
\text { and sex steroids }\end{array}$ & 0 & 0 & 0 & 1 \\
\hline H - hormone medicines for systemic use & 1 & 0 & 1 & 14 \\
\hline J - antimicrobial agents for systemic use & 11 & 5 & 1 & 10 \\
\hline $\begin{array}{l}\text { M - drugs affecting the musculoskeletal sys- } \\
\text { tem }\end{array}$ & 5 & 1 & 2 & 16 \\
\hline N - medicines affecting the nervous system & 8 & 7 & 8 & 0 \\
\hline P - antiparasitic agents, insecticidal repellents & 2 & 0 & 0 & 4 \\
\hline R - drugs affecting the respiratory system & 4 & 2 & 2 & 2 \\
\hline S - drugs affecting the sense organs & 5 & 1 & 1 & 116 \\
\hline V - various agents & 0 & 0 & 0 & \\
\hline Total & 57 & 27 & 34 & \\
\hline
\end{tabular}

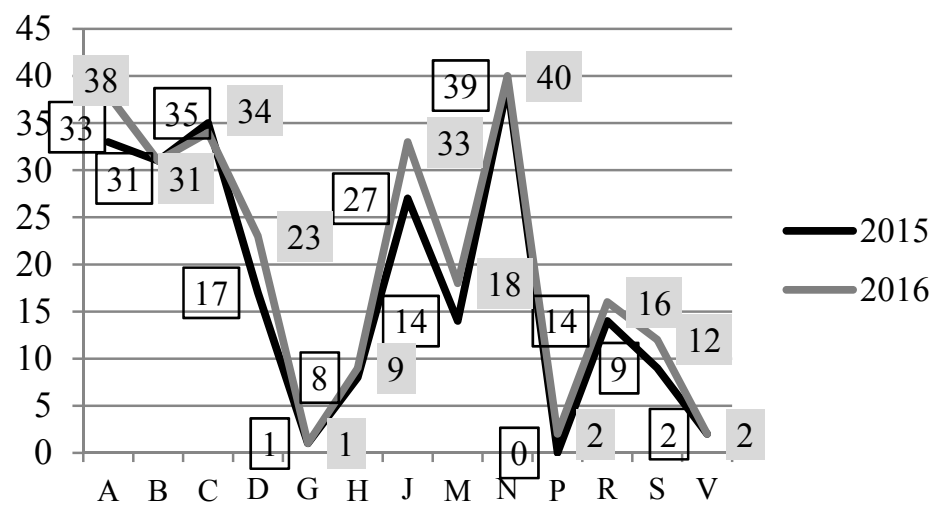

Fig. 2. Dynamics in the structure of consumption of trade names of medicines in $\mathrm{MMH}$ (in absolute numbers) in the period 2015-2016

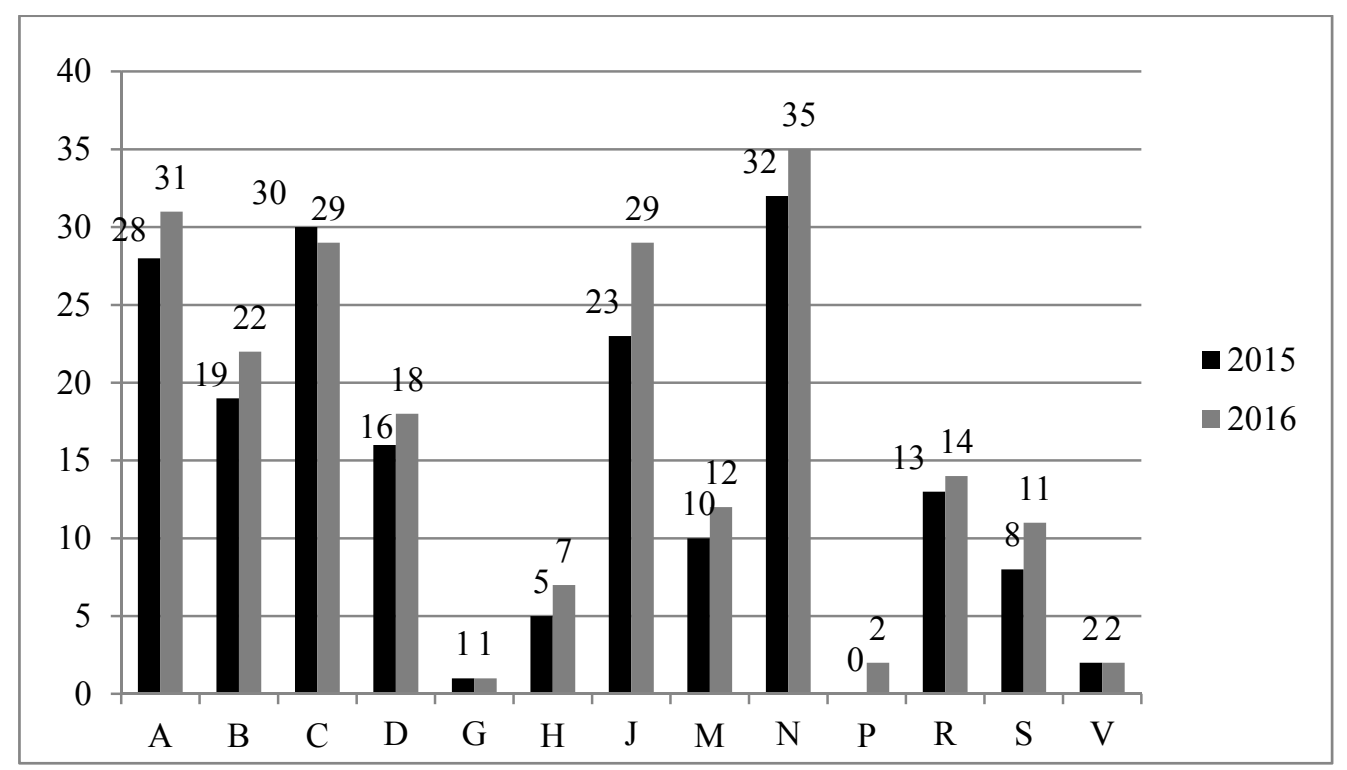

Fig. 3. Dynamics in the structure of consumption of INN drugs in the MMH (in absolute numbers) in the period 2015-2016 


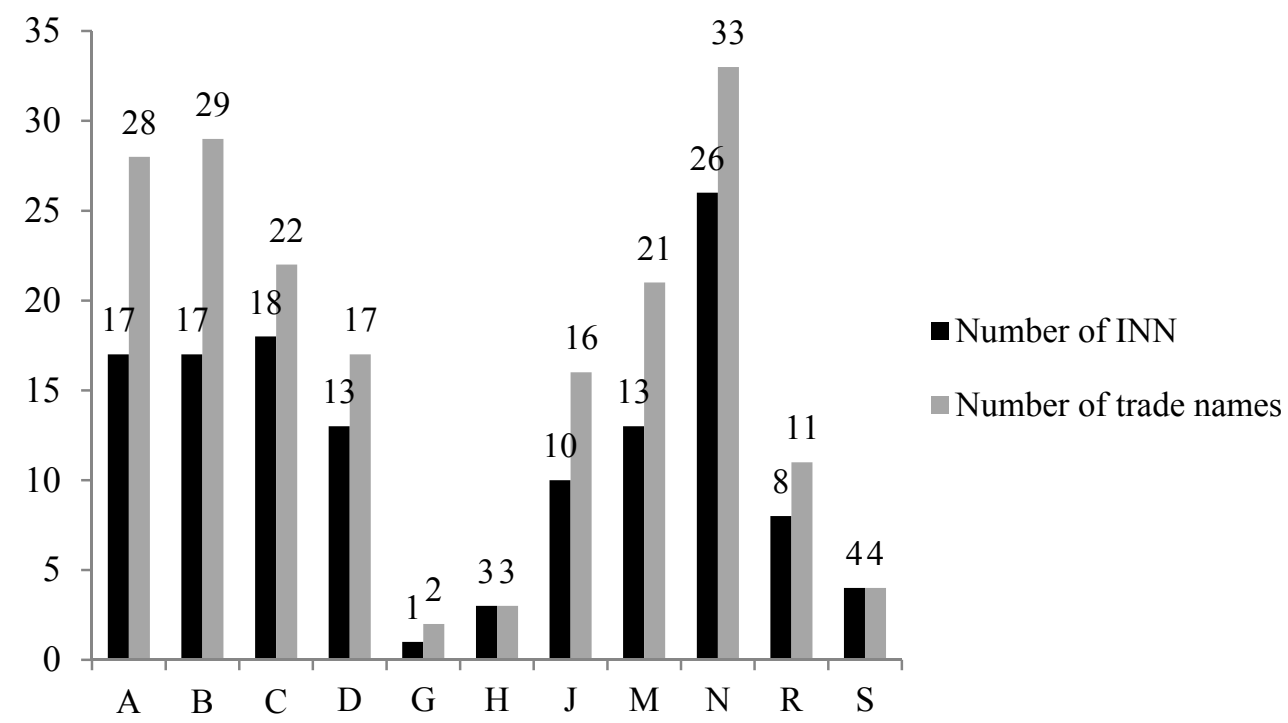

Fig. 4. Pattern of drug consumption in patients with a surgical profile of MMH for the first half of 2017

Analysis of drugs that were prescribed in the treatment of surgical patients-soldiers in the $\mathrm{MMH}$ found that $86 \%$ accounted for the preparations of seven major pharmacotherapeutic groups $(\mathrm{A}, \mathrm{B}, \mathrm{C}, \mathrm{D}, \mathrm{J}, \mathrm{N}, \mathrm{R})$ out of the twelve appointed. In pharmaceutical forms, the distribution looked as follows: 89 medicinal products are injectable solutions, 50 - infusion solutions, 30 - tablets, 11 ointments, 5 - sprays, 4 - solutions. Thus, the most popular medicinal forms in the treatment of surgical patients are solutions.

In accordance with the territorial principle of medical provision of the Armed Forces of Ukraine, the leading role in organizing the supply of medical equipment is assigned to the Military medical clinical centers of the regions. The financial and procurement activities of the Military medical clinical center as the institution of the zone of responsibility are related to the permanent monitoring and analysis of prices and terms of offers of wholesale supply companies. The basis for determining price indicators is taken by the Register of wholesale-selling prices in 2017.

Determination of the approximate amount of money for the half-year for the provision of medical support for military personnel of the surgical profile of the military mobile hospital in the total amount is $226990.09 \mathrm{UAH}$ (Table 4).

Table 4

The results of the $\mathrm{ABC}$ analysis of purchased drugs in the first half of 2017 for the treatment of surgical patients

\begin{tabular}{|c|c|c|c|c|}
\hline $\begin{array}{c}\text { Group of } \\
\text { drugs }\end{array}$ & $\begin{array}{c}\text { Number of } \\
\text { names }\end{array}$ & $\begin{array}{c}\text { Share in the total number of } \\
\text { names }\end{array}$ & $\begin{array}{c}\text { Financial costs for medicines, } \\
\text { UAH }\end{array}$ & $\begin{array}{c}\text { Share in total expendi- } \\
\text { tures }\end{array}$ \\
\hline A & 32 & 16.93 & 181032.2 & 79.75 \\
\hline B & 49 & 25.93 & 34478.85 & 15.19 \\
\hline C & 108 & 57.14 & 11479.04 & 5.06 \\
\hline Total & 189 & 100 & 226990.09 & 100 \\
\hline
\end{tabular}

After the analysis of the expenditure of funds for medicines $\mathrm{MMH}$ using ABC-analysis allowed to determine the group of the most expensive drugs. For 32 drugs included in group A (16.93\% of the total nomenclature), $79.75 \%$ of funds were spent; for 49 preparations of group B $-15 \%$ of funds; for 108 preparations of group C - $5 \%$ of total costs. The major part of the funds in the structure of drug therapy expenditures was spent on antimicrobial agents $(27.2 \%)$, a significant proportion was made up of drugs affecting the blood system $(17 \%)$ and the musculoskeletal system $(14 \%)$. In class A antimicrobial agents remain in the leader, in class $\mathrm{B}$ - drugs affecting the musculoskeletal system, in the class $\mathrm{C}$ - drugs affecting the cardiovascular system. In the structure of the total number of medicinal products (189), the most specific weight belongs to groups of drugs that affect the nervous system, hematopoietic and digestive systems $(33,29$ and 28 drug positions, respectively). In class $\mathrm{A}$, a group of drugs af- fecting the nervous system predominates in the B-drug class, affecting the digestive system, in the C-drug class, which affect the cardiovascular system.

\section{Conclusions from the conducted research and} prospects for further development of this field

1. The structure of the incoming flow of sanitary losses in the MMH during the ATO period has a reliable tendency to reduce the share of combat sanitary losses and increase the share of non-combat sanitary losses. The main nosological forms of diseases among military servicemen are diseases of the respiratory system, cardiovascular system and neurological diseases.

2. The dynamics of drug consumption, used in the treatment regimens of surgical patients of MMH was established. The most popular are groups of drugs that affect the digestive tract and metabolism, the nervous system, the blood system and hematopoiesis, the cardiovascular system and 
antimicrobial agents. A progressive tendency to increase the use of modern drugs of this group was determined.

3 . The results of the ABC-analysis made it possible to approve the rationalization of costs in the treatment of surgical patients of $\mathrm{MMH}$, the adequacy of the cost of drug therapy for a nosological unit of the disease. The leaders of consumption in money terms were representatives of a group of antimicrobial agents, in quantitative terms - drugs that affect the nervous system.

\section{References}

1. Miroshnichenko, Yu. V. Organizatsionno-metodicheskie podhody k normirovaniyu meditsinskogo imushchestva dlya voyskovogo i korabel'nogo zven'ev meditsinskoy sluzhby Vooruzhennyh sil v sovremennyh usloviyah [Text] / Yu. V. Miroshnichenko, A. B. Goryachev, R. A. Golubenko // Vestnik rossiyskoy voenno-meditsinskoy akademii. - 2014. - Issue 4 (48). - P. $185-192$.

2. Rudenko, V. V. Retrospektivniy analiz razvitiya sistemy normirovannogo raspredeleniya meditsinskogo imushchestva $\mathrm{V}$ voenno-meditsinskoy sluzhbe [Text] / V. V. Rudenko // Voennaya meditsina. - 2012. - Issue 2. - P. 92-97.

3. Shmatenko, A. P. Medikamentoznoe obespechenie postradavshih s torakoabdominal'noy travmoy [Text] / A. P. Shmatenko, R. L. Pritula, A. N. Solomenniy // Farmatsevticheskiy zhurnal. - 2013. - Issue 4. - P. 19-25.

4. Solomenniy, A. N. Obosnovanie normy medikamentoznogo obespecheniya postradavshih voennosluzhashchih s torakoabdominal'noy travmoy [Text] / A. N. Solomenniy // Vestnik farmatsii. - 2014. - Issue 3. - P. 58-61.

5. Gul'pa, V. S. Normirovanie infuzionnyh sredstv i izgotovlenie ih v polevyh usloviyah dlya okazaniya kvalifitsirovannoy meditsinskoy pomoshchi v vooruzhennyh konfliktah [Text] / V. S. Gul'pa, G. P. Hitriy, E. S. Kozeev // Voennaya meditsina Ukrainy. - 2012. Vol. 12, Issue 2. - P. 77-82.

6. Zaporozhan, V. M. Vzaimodeystvie voennoy i grazhdanskoy meditsiny v ATO [Text] / V. N. Zaporozhan, V. P. Maydanyuk, A. V. Iva // Problemy voennogo zdravoohraneniya. - 2016. - Vol. 36. - P. 304-306.

7. Andronatiy, V. B. Sistema meditsinskogo obespecheniya Vooruzhennyh Sil Ukrainy: sovremennoe sostoyanie i napravleniya razvitiya s uchetom tendentsii izmeneniy $\mathrm{v}$ poryadke primeneniya voysk [Text] / V. B. Andronatiy, V. A. Zhahovskiy, A. Yu. Bulah, V. G. Livinskiy // Nauka i oborona. - 2014. - Issue 3. - P. $23-29$.

8. Prikaz Ministra oborony Ukrainy ot 20.02.2008 No. 57 "Ob utverzhdenii Polozheniya o voennom mobil'nom gospitale (mnogoprofil'nyy na 100 koek)".

9. Frolov, M. Yu. Metodika provedeniya AVS/VEN-analiza [Text] / M. Yu. Frolov, O. N. Barkanova, O. V. Shatalova // Lekarstvenniy vestnik. - 2012. - Vol. 46, Issue 6. - P. 3-6.

10. Matyuha, L. F. Raschet potrebnosti $\mathrm{v}$ lekarstvennyh sredstvah, soderzhashchih kontroliruemye veshchestva [Text]: metod. rek. / L. F. Matyuha, T. P. Avramenko, I. I. Lesnoy, N. G. Goyda. - Kyiv, 2015. - 20 p.

11. Agripishin, S. V. Analiz vhodyashchego potoka sanitarnyh poter' v 59 mobil'nyy voennyy gospital' vo vremya antiterroristicheskoy operatsii za 2014-2015 gg. [Text] / S. V. Agripishin, I. K. Sereda // Mater. konferentsii molodyh uchenyh Ukrainskoy voenno-meditsinskoy akademii. - Kyiv: ChP «Chalchinskiy», 2017. - P. 12-13.

Рекомендовано до публікаиії д-р фарм. наук Шматенко О. П. Дата надходження рукопису 13.10.2017

Oksana Bielozorova, Head of Department, Scientific-organizational department, Ukrainian Military Medical Academy, Melnykova str., 24, Kyiv, Ukraine, 46050 